SAARC J. Agri., 12(1), 09-19(2014)

\title{
INTERCROPPING AUS RICE WITH DIFFERENT SEED RATES OF BLACKGRAM AS FODDER
}

\author{
M.S. Uddin ${ }^{1}$ M.A.R. Sarkar ${ }^{2}$ and M. A. M. Miah ${ }^{2}$ \\ Department of Agronomy, Bangladesh Agricultural University, Mymensingh- 2202
}

\begin{abstract}
A field experiment was conducted to explore the feasibility of blackgram fodder production in Aus rice as intercropping system at the Agronomy Field Laboratory, Bangladesh Agricultural University, Mymensingh from March to July 2009. The experiment was laid out in a randomized complete block design with three replications. The fodder crop was sown at various densities as sole crop for comparison. Growth parameters, yield components and yields were higher in sole cropping. Economic analysis reveals that intercropping systems showed better performance in terms of gross, net return and benefit cost ratio compared to sole cropping of main or fodder crop at various plant populations per unit area. Intercropping blackgram as fodder with $50 \mathrm{~kg}^{\mathrm{seed} \mathrm{ha}} \mathrm{ha}^{-1}$ in $\mathrm{Aus}$ rice row sowing of $25 \mathrm{~cm}$ would be the promising fodder production with minimum grain yield loss of rice with higher profit.
\end{abstract}

Keywords: Blackgram fodder, Aus rice, Intercrop, Yield.

\section{INTRODUCTION}

Bangladesh is a densely populated country. In Bangladesh, only 9.09 million hectare land is available to feed 146.70 million people (AIS, 2012). The average availability of meat and milk in Bangladesh is very meagre compared to other parts of the world. Malnutrition is a major problem in the country. Eighty eight percent of the population suffers from protein deficiency (Kabir et al., 2005). Malnutrition may be minimized to a large extent by means of making meat and milk available because meat is a rich source of protein and milk supplies minerals, food energy also protein, fat, carbohydrate and vitamins. Livestock is important assets to the farmers as well as to the national economy in addition to their contribution to the nation's food supply. The role of livestock in cultivation, providing manure for crop production and fuel for cooking, rural transportation and threshing makes economic importance for Bangladesh agriculture. Animal droppings may play an important role to improve soil fertility because in Bangladesh soil fertility is deteriorating day by day due to intensive crop cultivation, introduction of high yielding crop varieties, use of less amount of organic matter and improper soil and crop management practices (Hossain et al.,1995). But in the country there is neither any planned program of fodder production nor the farmers are able to set aside a part of their land solely for fodder production. There is high pressure on land for

*Corresponding author email: shahabipm@gmail.com

${ }^{1}$ Senior IPM Specialist, Integrated Pest Management (IPM) $2^{\text {nd }}$ Phase Project, Dept. of Agricultural Extension, Khamarbari, Dhaka-1215, Bangladesh

${ }^{2}$ Professor, Department of Agronomy, Bangladesh Agricultural University, Mymensingh-2200, Bangladesh

${ }^{2}$ MS student, Department of Agronomy, Bangladesh Agricultural University, Mymensingh-2200, Bangladesh

Received: 10.02 .2013 
production of food for human being. Consequently there is a huge deficit of feed and fodder in the country and the situation is getting worse day by day. To alleviate the situation and to improve the declining livestock productivity it is indispensable to increase fodder production.

Growing fodder as inter or mixed crop with main crop may be effective method of fodder production in Bangladesh. The diversity in the existing inter-and mixed cropping practiced in the tropics has been documented by Beets (1982). Intercropping is a simple and expensive strategy and has been recognized as a potentially benefited technology to increase crop production due to its substantial yield advantage than sole cropping (Awal et al., 2006). Singh et al. (1992) observed that when rice was intercropped with blackgram (Vigna mungo) in 2:1 or 3:1 row ratios; the grain yield of rice was $2.28 \mathrm{tha}^{-1}$ as sole crop and 1.51 to $1.88 \mathrm{t} \mathrm{ha}^{-1}$ when intercropped. On the other hand, blackgram yielded $0.44 \mathrm{tha}^{-1}$ when grown alone and 0.16 to $0.71 \mathrm{t} \mathrm{ha}^{-1}$ when intercropped. Sarma and Shyam (1992) observed that in summer direct-seeded rice when intercropped with summer pulses, the highest rice equivalent yield $\left(1.97 \mathrm{tha}^{-1}\right)$ and the highest net return were obtained at rice + green gram in 2:1 row ratio. Yield of $A$ A s rice and mungbean as fodder were decreased in intercropping compared to their sole crops; but intercropping was superior to sole cropping in terms of gross return, net return, land equivalent ratio, rice equivalent yield and benefit-cost ratio (Kader et al, 1999). Midya et al. (2005) found that intercropping reduced the yield of component crops compared to the respective pure stands. However, sowing of blackgram in rice $30 \mathrm{~cm}$ apart after one weeding was the most remunerative system for weed smothering and offered the highest riceequivalent yield $\left(2711 \mathrm{~kg} \mathrm{ha}^{-1}\right)$. With minimum grain yield loss and higher monetary benefit, maize fodder was grown successfully as relay cropping at $25 \mathrm{~cm} \times 15 \mathrm{~cm}$ spacing in transplant Aman rice (Uddin et al., 2012). Some research work was done but blackgram as fodder crop as mearge. So, this research work was undertaken to study the feasibility of blackgram fodder production in Aus rice as intercrop without or with minimum loss of main crop.

\section{MATERIALS AND METHODS}

The experiment was conducted at the Agronomy Field Laboratory, Bangladesh Agricultural University, Mymemsingh from March to July 2009. The experimental site was the Old Brahmaputra Floodplain having dark grey soils (UNDP and FAO, 1988). The experimental land was medium high in topography having Non-calcareous Dark Grey soil under Agroecological zone (AEZ-9) belonging to the Sonatala series (BARC, 1997). The soil status of the experimental plot was characterized by silt loam in texture, slightly acidic, organic matter below $1.50 \%$ and other nutrients content were medium to low (Pramanik, 2006). The climate of the experimental site is wet, humid and sub-tropical. Main characteristics of the climate are heavy monsoon rainfall, short winter and long dry spell in pre-monsoon. The experiment was laid out in a randomized complete block design with three replications. The unit plot size was $4.0 \mathrm{~m} \times 2.5 \mathrm{~m}$. The experimental treatments were: $A u s$ rice sole sown in $25 \mathrm{~cm}$ apart $\left(\mathrm{T}_{1}\right)$, Black gram $50 \mathrm{~kg}$ seed ha ${ }^{-1}$ (sole) $\left(\mathrm{T}_{2}\right)$, Aus rice + Black gram $50 \mathrm{~kg} \mathrm{seed} \mathrm{ha}^{-1}\left(\mathrm{~T}_{3}\right)$, Black gram $55 \mathrm{~kg}$ seed ha ${ }^{-1}$ (sole) $\left(\mathrm{T}_{4}\right)$, Aus rice + Black gram $55 \mathrm{~kg}^{-1}$ eed ha- ${ }^{-1}\left(\mathrm{~T}_{5}\right)$, Black gram 60 $\mathrm{kg}$ seed ha ${ }^{-1}$ (sole) $\left(\mathrm{T}_{6}\right)$, Aus rice + Black gram $60 \mathrm{~kg}$ seed ha ${ }^{-1}\left(\mathrm{~T}_{7}\right)$, Black gram $65 \mathrm{~kg}$ seed $\mathrm{ha}^{-1}$ (sole) $\left(\mathrm{T}_{\mathrm{B}}\right)$, Aus rice + Black gram $65 \mathrm{~kg}$ seed ha ${ }^{-1}\left(\mathrm{~T}_{9}\right)$, Black gram $70 \mathrm{~kg}$ seed ha ${ }^{-1}$ (sole) $\left(\mathrm{T}_{10}\right)$, Aus rice + Black gram $70 \mathrm{~kg}$ seed ha ${ }^{-1}\left(\mathrm{~T}_{11}\right)$, Black gram $75 \mathrm{~kg}^{-1}$ see ha ${ }^{-1}$ (sole) $\left(\mathrm{T}_{12}\right)$, Aus rice + Black gram $75 \mathrm{~kg}$ seed ha ${ }^{-1}\left(\mathrm{~T}_{13}\right)$, Black gram $80 \mathrm{~kg}$ seed ha ${ }^{-1}$ (sole) $\left(\mathrm{T}_{14}\right)$ and Aus rice + Black gram $80 \mathrm{~kg}$ seed ha ${ }^{-1}\left(\mathrm{~T}_{15}\right)$.

A modern rice variety (BR 21) was used as Aus rice. Blackgram variety (BARI mash 3) was used as sole and intercrop with $A u s$ rice. $A u s$ rice seeds were sown as per treatment on 16 
March 2009 at the rate of $60 \mathrm{~kg} \mathrm{ha}^{-1}$. Seeds of blackgram were sown in the sole and Aus rice sown plots on 16 March 2009 with seven seed rate for each plot as per treatment. The fertilizers for Aus rice sole crop at the rate 65-10-20-7-2 $\mathrm{kg} \mathrm{ha}^{-1}$ and intercrop 90-15-25-10-2 $\mathrm{kg} \mathrm{ha}^{-1}$ of N-P-K-S-Zn, respectively. At final land preparation the experimental plots were fertilized with full dose of $P, K, S$ and $1 / 2$ of $N$ and rest $N$ at 35 DAS. Fertilizers for intercrop with $A$ us rice were adjusted. The fertilizers for blackgram fodder sole were applied at the rate 20-10-20-7 kg ha ${ }^{-1}$ of N-P-K-S, respectively. Three times weeding were done at 20, 35 and 50 DAS. There was no need for irrigation during the growing period of the crop. At dough stage the crop was attacked by rice bug (Leptocorisa oratorius) and it was successfully controlled by spraying Chlorpyriphos (20 liquid) at the rate of $1 \mathrm{ml} \mathrm{l}^{-1}$. There was no significant incidence of diseases during the growing period of the crop and hence no disease control measure was taken. Aus paddy was harvested with sickle on 30 June 2009 when $80 \%$ paddies turned golden colour and the panicle curvature. Grain and straw yields were recorded and converted to t ha ${ }^{-1}$ as per treatment at $14 \%$ moisture content. Blackgram fodder was harvested on 18 May 2009 at pod formation stage and green fodder yield was recorded. Initial weight of the sample plants were recorded treatment and replication-wise. Sample plants were packed in the brown paper envelop separately and dried in an electric oven at $65^{\circ} \mathrm{C}$ for 72 hours to a constant weight. Dry fodder yield was recorded and converted to $\mathrm{tha}^{-1}$.

Data were recorded on yield contributing characters and yields of main crop and fodder crop. Economic return was calculated on the basis of market price. Analysis of variance (ANOVA) was done with the help of computer package M-STAT. Differences among the treatment means were adjudged by Duncan's Multiple Range Test (Gomez and Gomez, 1984).

The harvest index (HI) was calculated using the formula:

$\mathrm{HI}(\%)=\frac{\text { Grain yield }}{\text { Biological yield }} \times 100$

The cost of cultivation, gross return and net return $\mathrm{ha}^{-1}$ were computed on the basis of prevailing market price of different commodities as follows:

A. Gross return (Tk. ha $\left.{ }^{-1}\right)$

i) Sole main crop = Value of grain + Value of straw

ii) Sole fodder crop $=$ Value of fodder yield

iii) Intercrops $=$ Value of grain + Value of straw + Value of fodder yield

B. Net return $\left(\right.$ Tk. ha $\left.{ }^{-1}\right)=$ Gross return $\left(T k . h^{-1}\right)-$ Total cost of cultivation $\left(\right.$ Tk. ha $\left.{ }^{-1}\right)$

C. Benefit cost ratio $=\frac{\text { Gross return }\left(\text { Tk. ha } \mathrm{ha}^{-1}\right)}{\text { Total cost }(\text { variable }) \text { of cultivation }\left(\text { Tk. ha } \mathrm{ha}^{-1}\right)}(\mathrm{Pal}$ et al., 1985)

RESULTS AND DISCUSSION

\section{Yield attributes of Aus rice}

Number of effective tillers $\mathbf{m}^{-2}$

Number of effective tillers $\mathrm{m}^{-2}$ of $A$ us rice was significantly affected by blackgram fodder intercropping at different seed rates (Table 1). The maximum number of effective tillers $\mathrm{m}^{-2}$ (282.6) was observed in sole aus rice sown in $25 \mathrm{~cm}$ apart, which was followed by Aus rice in row + blackgram fodder at $50 \mathrm{~kg}$ seed ha ${ }^{-1}(266.1)$. The lowest number of effective tillers $\mathrm{m}^{-2}$ (157.6) was found in row seeded sole aus rice (188.1). Among the intercropping systems, the 
number of effective tillers $\mathrm{m}^{-2}$ showed the best performance (266.1) when blackgram fodder was intercropped at $50 \mathrm{~kg}$ seed ha ${ }^{-1}$ in row seeded aus rice. Significant variation of Aus rice effective tillers $\mathrm{m}^{-2}$ could be due to increase seed rate in blackgram as fodder.

\section{Number of grains panicle ${ }^{-1}$}

Number of grains panicle ${ }^{-1}$ of Aus rice was significantly affected by blackgram fodder intercropping at different seed rates (Table 1). The maximum number of grains panicle ${ }^{-1}$ (111.70) was observed in sole aus rice sown in row $25 \mathrm{~cm}$ apart, which was similar to Aus rice in row + blackgram fodder at 50,55 , and $60 \mathrm{~kg}$ seed ha ${ }^{-1}$. Similar trend of performance regarding number of grains panicle ${ }^{-1}$ was observed by Mandal et al. (1989). The lowest number of grains panicle ${ }^{-1}(86.09)$ was found in row seeded aus rice + blackgram fodder at 80 $\mathrm{kg}$ seed rate ha ${ }^{-1}$, which was at par with row seeded aus rice + blackgram fodder at 50 and 55 $\mathrm{kg}$ seed $\mathrm{ha}^{-1}$. Among the intercropping systems, the number of grains panicle $\mathrm{e}^{-1}$ showed the best performance (110.00) when blackgram fodder was intercropped at $55 \mathrm{~kg} \mathrm{seed} \mathrm{ha}^{-1}$ in row seeded Aus rice. Variation of Aus rice number of grains panicle ${ }^{-1}$ might be due to increase in blackgram fodder seed rate.

Table 1.Yield and yield components of Aus rice in Aus rice-black gram intercropping system

\begin{tabular}{|c|c|c|c|c|c|c|}
\hline Treatment & $\begin{array}{c}\text { No. of } \\
\text { effective } \\
\text { tillers } \mathrm{m}^{-2}\end{array}$ & $\begin{array}{l}\text { No. of } \\
\text { grains } \\
\text { panicle }^{-1}\end{array}$ & \begin{tabular}{|l|}
1000 -grain \\
weight $(\mathrm{g})$
\end{tabular} & $\begin{array}{l}\text { Grain } \\
\text { yield } \\
\left(\mathrm{t} \mathrm{ha}^{-1}\right)\end{array}$ & $\begin{array}{c}\text { Straw yield } \\
\left(\mathrm{t} \mathrm{ha}^{-1}\right)\end{array}$ & $\begin{array}{c}\text { Harvest } \\
\text { index (\%) }\end{array}$ \\
\hline $\begin{array}{l}\text { Aus rice sole sown in } \\
25 \mathrm{~cm} \text { apart }\left(\mathrm{T}_{1}\right)\end{array}$ & $157.6 \mathrm{f}$ & $86.09 \mathrm{~d}$ & 24.03 & $2.79 \mathrm{a}$ & $4.19 \mathrm{a}$ & $39.97 \mathrm{a}$ \\
\hline $\begin{array}{l}\text { Aus rice + Black } \\
\text { gram } 50 \text { kg seed ha } \\
\left(\mathrm{T}_{3}\right)\end{array}$ & $188.1 \mathrm{e}$ & $90.95 \mathrm{~cd}$ & 24.00 & $2.67 \mathrm{ab}$ & $4.02 \mathrm{ab}$ & $39.88 \mathrm{a}$ \\
\hline $\begin{array}{l}\text { Aus rice + Black } \\
\text { gram } 55 \mathrm{~kg} \mathrm{seed} \mathrm{ha}^{-1} \\
\left(\mathrm{~T}_{5}\right)\end{array}$ & $203.9 \mathrm{de}$ & $93.02 \mathrm{~cd}$ & 23.75 & $2.55 \mathrm{~b}$ & $3.94 \mathrm{a}-\mathrm{c}$ & $39.16 \mathrm{~b}$ \\
\hline $\begin{array}{l}\text { Aus rice + Black } \\
\text { gram } 60 \mathrm{~kg} \mathrm{seed} \mathrm{ha}^{-1} \\
\left(\mathrm{~T}_{7}\right)\end{array}$ & $218.5 \mathrm{~d}$ & $99.87 \mathrm{bc}$ & 23.22 & $2.35 \mathrm{c}$ & $3.50 \mathrm{~cd}$ & $38.02 \mathrm{c}$ \\
\hline $\begin{array}{l}\text { Aus rice + Black } \\
\text { gram } 65 \mathrm{~kg} \mathrm{seed} \mathrm{ha}^{-1} \\
\left(\mathrm{~T}_{9}\right)\end{array}$ & $240.1 \mathrm{c}$ & $103.20 \mathrm{ab}$ & 23.11 & $2.23 \mathrm{~cd}$ & $3.65 \mathrm{~b}-\mathrm{d}$ & $37.96 \mathrm{c}$ \\
\hline $\begin{array}{l}\text { Aus rice + Black } \\
\text { gram } 70 \mathrm{~kg} \text { seed } \mathrm{ha}^{-1} \\
\left(\mathrm{~T}_{11}\right)\end{array}$ & $254.0 \mathrm{bc}$ & $110.00 \mathrm{a}$ & 23.07 & $2.11 \mathrm{de}$ & $3.45 \mathrm{~cd}$ & $37.89 \mathrm{c}$ \\
\hline $\begin{array}{l}\text { Aus rice + Black } \\
\text { gram } 75 \mathrm{~kg} \mathrm{seed} \mathrm{ha}^{-1} \\
\left(\mathrm{~T}_{13}\right)\end{array}$ & $266.1 \mathrm{ab}$ & $109.20 \mathrm{ab}$ & 23.01 & $2.02 \mathrm{e}$ & $3.34 \mathrm{~d}$ & $37.70 \mathrm{~d}$ \\
\hline $\begin{array}{l}\text { Aus rice }+ \text { Black } \\
\text { gram } 80 \text { kg seed ha } \\
\left(T_{15}\right)\end{array}$ & $282.6 \mathrm{a}$ & $111.70 \mathrm{a}$ & 23.00 & $1.97 \mathrm{e}$ & $3.26 \mathrm{~d}$ & $37.66 \mathrm{~d}$ \\
\hline CV (\%) & 5.37 & 5.18 & 4.98 & 3.20 & 7.22 & 0.22 \\
\hline
\end{tabular}


In a column, figures having similar letters or without letter do not differ significantly whereas figures having dissimilar letters differ significantly as per Duncan's Multiple Range Test (DMRT).

\section{Thousand grain weight}

Weight of 1000 grains of Aus rice was not significantly affected by blackgram fodder intercropping at different seed rates (Table 1), which indicated that blackgram fodder could be grown successfully as intercrop in different seed rates in Aus rice without affecting 1000-grain weight. Numerically the highest 1000 -grain weight ( $24.03 \mathrm{~g}$ ) was observed in sole Aus rice in $25 \mathrm{~cm}$ apart and the lowest $(23.00 \mathrm{~g})$ in $A$ us rice in row + blackgram fodder $80 \mathrm{~kg}$ seed ha ${ }^{-1}$.

\section{Grain yield}

Grain yield of $A u$ s rice was significantly affected by blackgram fodder intercropping at different seed rates. The highest grain yield $\left(2.79 \mathrm{t} \mathrm{ha}^{-1}\right)$ was observed in sole Aus rice in 25 $\mathrm{cm}$ apart, which was at par with $A$ us rice in row + blackgram fodder at $50 \mathrm{~kg}$ seed ha ${ }^{-1}$. The improvement of yield components viz., number of effective tillers hill ${ }^{-1}$ and $\mathrm{m}^{-2}$, number of grains panicle ${ }^{-1}$ and weight of 1000-grains in these treatments contributed mainly to the improvement of grain yield of Aus rice. Increased number of effective tillers $\mathrm{m}^{-2}$ might be due to less attack of insect pests, which was similar to the results of Jhansi (2004), who reported that intercropping of cowpea with cereals resulted in the lowest percentage of dead heart and stem borer infestation. The lowest grain yield $\left(1.97 \mathrm{tha}^{-1}\right)$ was found in Aus rice in row + blackgram fodder at $80 \mathrm{~kg}$ seed ha-1, which was at par with Aus rice in row + blackgram fodder at 70 and $75 \mathrm{~kg}$ seed ha ${ }^{-1}$. Among the intercropping systems, the grain yield showed the best performance $\left(2.67 \mathrm{tha}^{-1}\right)$ when blackgram fodder was intercropped at $50 \mathrm{~kg}$ seed ha ${ }^{-1}$ in Aus rice sown in rows. Significant variation of Aus rice grain yield might be due to increase in blackgram fodder plants population unit ${ }^{-1}$ area.

\section{Straw yield}

Straw yield of Aus rice was significantly affected by blackgram fodder intercropping at different seed rates (Table 1). Higher straw yield $\left(4.19 \mathrm{tha}^{-1}\right)$ was observed in sole Aus rice in $25 \mathrm{~cm}$ apart, which was at par with Aus rice in row + blackgram fodder at 50 and $55 \mathrm{~kg}$ seed $\mathrm{ha}^{-1}$. The lowest straw yield $\left(3.26 \mathrm{tha}^{-1}\right)$ was found in Aus rice in row + blackgram fodder at $80 \mathrm{~kg}$ seed rate ha ${ }^{-1}$, which was at par with $A$ Aus rice in row + blackgram fodder at 60, 65, 70 and $75 \mathrm{~kg}$ seed ha $\mathrm{h}^{-1}$. Among the intercropping systems, the straw yield showed the best performance $\left(4.02 \mathrm{tha}^{-1}\right)$ when blackgram fodder was intercropped at $50 \mathrm{~kg}$ seed ha ${ }^{-1}$ in row aus rice. Variation of $A$ us rice straw yield might be due to increase in blackgram fodder plants population unit ${ }^{-1}$ area.

\section{Harvest index (\%)}

Harvest index \% of Aus rice was significantly affected by blackgram fodder intercropping at different seed rates (Table 1). The highest harvest index (39.97\%) was observed in sole Aus rice in $25 \mathrm{~cm}$ apart, which was at par with Aus rice in row + blackgram fodder at $50 \mathrm{~kg}$ seed $\mathrm{ha}^{-1}$. The grain and straw yields in these treatments contributed mainly to the improvement of harvest index of Aus rice. The lowest harvest index (37.66\%) was found in Aus rice in row + blackgram fodder at $80 \mathrm{~kg}$ seed rate ha $\mathrm{ha}^{-1}$, followed by $75 \mathrm{~kg}$ seed $\mathrm{ha}^{-1}$. Among the intercropping systems, the harvest index showed the best performance $(39.88 \%)$ when blackgram fodder was intercropped at $50 \mathrm{~kg}$ seed ha ${ }^{-1}$ in Aus rice row sowing. 


\section{Blackgram fodder}

\section{Plant height}

Plant height of blackgram fodder was significantly affected by seed rate of blackgram in Aus rice-blackgram intercropping system and sole cropping (Table 2). The maximum plant height $(48.59 \mathrm{~cm})$ was observed in blackgram fodder sole cropping at $50 \mathrm{~kg} \mathrm{seed} \mathrm{ha}^{-1}$, which was at par with $A$ us rice in row + blackgram fodder at $50 \mathrm{~kg}$ seed ha ${ }^{-1}$. The lowest plant height of blackgram $(42.10 \mathrm{~cm})$ was found in Aus rice in row + blackgram fodder at $80 \mathrm{~kg}$ seed ha ${ }^{-1}$ which was at par with blackgram as fodder sole cropping at $80 \mathrm{~kg} \mathrm{seed} \mathrm{ha}^{-1}$. Among the intercropping systems, plant height of blackgram showed the best performance $(48.05 \mathrm{~cm})$ in Aus rice in row + blackgram fodder at $50 \mathrm{~kg}^{\mathrm{seed} \mathrm{ha}} \mathrm{h}^{-1}$. Significant variation of plant height of blackgram fodder might be due to increase in blackgram fodder seed rate and intercropping with Aus rice.

\section{Number of branches plant ${ }^{-1}$}

Number of branches plant ${ }^{-1}$ of blackgram fodder was significantly affected by treatments (Table 2). The maximum number of branches plant ${ }^{-1}(3.47)$ was observed in blackgram fodder sole cropping at $50 \mathrm{~kg}$ seed ha ${ }^{-1}$, which was at par with Aus rice in row + blackgram fodder at $50 \mathrm{~kg}$ seed ha ${ }^{-1}$ and blackgram fodder sole cropping at $55 \mathrm{~kg} \mathrm{seed} \mathrm{ha}^{-1}$. The lowest number of branches plant ${ }^{-1}$ of blackgram (2.47) was found in Aus rice in row + blackgram fodder at 80 $\mathrm{kg}$ seed ha $\mathrm{a}^{-1}$, which was at par with blackgram fodder sole cropping at 75 and $80 \mathrm{~kg}$ seed ha ${ }^{-1}$ and $A$ A s rice in row + blackgram fodder at $75 \mathrm{~kg}$ seed ha ${ }^{-1}$. Among the intercropping systems, number of branches plant ${ }^{-1}$ of blackgram showed the best performance (3.33) in Aus rice in row + blackgram fodder at $50 \mathrm{~kg}$ seed ha ${ }^{-1}$. Variation of number of branches plant ${ }^{-1}$ of blackgram fodder might be due to increase in blackgram fodder seed rate and intercropping with Aus rice.

\section{Number of leaves plant ${ }^{-1}$}

Number of leaves plant ${ }^{-1}$ of blackgram fodder was significantly affected by treatments (Table $2)$. The number of leaves plant ${ }^{-1}(10.40)$ was observed in blackgram fodder sole cropping at $50 \mathrm{~kg}$ seed ha ${ }^{-1}$, which was at par with Aus rice in row + blackgram fodder at 50,55 and $60 \mathrm{~kg}$ seed ha ${ }^{-1}$ and blackgram fodder sole cropping at 55,60 and $65 \mathrm{~kg}^{2}$ seed ha- ${ }^{-1}$. The lowest number of leaves plant ${ }^{-1}$ of blackgram (8.20) was found in Aus rice in row + blackgram fodder at $80 \mathrm{~kg}$ seed ha ${ }^{-1}$, which was at par with blackgram fodder sole cropping at 70,75 and $80 \mathrm{~kg}$ seed ha ${ }^{-1}$ and Aus rice in row + blackgram fodder at 70 and $75 \mathrm{~kg}$ seed ha ${ }^{-1}$. Among the intercropping systems, number of leaves plant ${ }^{-1}$ of blackgram showed the best performance (10.33) in Aus rice in row + blackgram fodder at $50 \mathrm{~kg}^{\mathrm{seed} \mathrm{h}} \mathrm{h}^{-1}$. Variation of number of leaves plant ${ }^{-1}$ of blackgram fodder might be due to increase in blackgram fodder seed rate and intercropping with $A$ us rice.

Plants $\mathbf{m}^{-2}$

Plants $\mathrm{m}^{-2}$ of blackgram fodder was significantly affected by seed rate of blackgram in Aus rice-blackgram intercropping system and sole cropping (Table 2). The maximum plants $\mathrm{m}^{-2}$ (50.33) was observed in blackgram fodder sole cropping at $80 \mathrm{~kg}$ seed ha-1, which was similar to blackgram fodder sole cropping at $75 \mathrm{~kg}$ seed ha-1 and Aus rice in row + blackgram at 75 and $80 \mathrm{~kg}$ seed ha ${ }^{-1}$. The lowest plants $\mathrm{m}^{-2}$ (37.33) was found in Aus rice in row + blackgram fodder at $50 \mathrm{~kg}$ seed ha $\mathrm{h}^{-1}$, which was similar to blackgram fodder sole cropping at 50 and 55 $\mathrm{kg}$ seed ha ${ }^{-1}$ and Aus rice in row + blackgram fodder at $55 \mathrm{~kg} \mathrm{seed} \mathrm{ha}^{-1}$. Variation of plants $\mathrm{m}^{-2}$ 
of blackgram fodder might be due to increase in blackgram fodder seed rate and intercropping with Aus rice.

\section{Weight of individual plant}

Weight of individual plant of blackgram fodder was significantly affected by seed rate of blackgram in Aus rice-blackgram intercropping system and sole cropping (Table 2). The maximum weight of individual plant $(47.87 \mathrm{~g})$ was observed in blackgram fodder sole cropping at $50 \mathrm{~kg}$ seed ha ${ }^{-1}$, which was at par with Aus rice in row + blackgram fodder at 50 and $55 \mathrm{~kg}$ seed ha ${ }^{-1}$ and blackgram fodder sole cropping at 55 and $60 \mathrm{~kg} \mathrm{seed} \mathrm{ha}^{-1}$. The lowest weight of individual plant of blackgram (33.35 g) was found in Aus rice in row + blackgram fodder at $80 \mathrm{~kg}$ seed ha ${ }^{-1}$, which was at par with blackgram fodder sole cropping at $80 \mathrm{~kg}$ seed $\mathrm{ha}^{-1}$ and Aus rice in row + blackgram fodder at $75 \mathrm{~kg}$ seed $\mathrm{ha}^{-1}$. Variation of weight of individual plant of blackgram fodder might be due to increase in blackgram seed rate.

\section{Green fodder yield}

Green fodder yield of blackgram was significantly by treatment. Higher green fodder yield $\left(17.52 \mathrm{t} \mathrm{ha}^{-1}\right)$ was observed in blackgram fodder sole cropping at $80 \mathrm{~kg} \mathrm{seed} \mathrm{ha}^{-1}$, which was similar to blackgram sole cropping at $75 \mathrm{~kg}$ seed ha ${ }^{-1}$ and Aus rice in row + blackgram at 80 $\mathrm{kg}$ seed $\mathrm{ha}^{-1}$. The maximum plant population of blackgram in these treatments were mainly responsible for the highest green fodder yield. The lowest green fodder yield (11.98 tha $\left.\mathrm{th}^{-1}\right)$ was found in Aus rice in row + blackgram fodder at $50 \mathrm{~kg}$ seed ha ${ }^{-1}$, which was similar to blackgram fodder sole cropping at $50 \mathrm{~kg}$ seed ha ${ }^{-1}$. Among the intercropping systems, green fodder yield of blackgram showed the best performance $\left(17.27 \mathrm{t} \mathrm{ha}^{-1}\right)$ in Aus rice in $25 \mathrm{~cm}$ apart + blackgram at $80 \mathrm{~kg}$ seed ha ${ }^{-1}$. Variation of green fodder yield of blackgram might be due to increase seed rate in blackgram.

Table 2. Plant characters and yield of black gram fodder in Aus rice-black gram intercropping system

\begin{tabular}{|c|c|c|c|c|c|c|c|}
\hline Treatment & $\begin{array}{l}\text { Plant } \\
\text { height } \\
\text { (cm) }\end{array}$ & $\begin{array}{l}\text { No. of } \\
\text { branche } \\
\text { s plant }\end{array}$ & $\begin{array}{l}\text { No. of } \\
\text { leaves } \\
\text { plant }^{-1}\end{array}$ & $\begin{array}{l}\text { Plants } \\
\mathrm{m}^{-2}\end{array}$ & $\begin{array}{l}\text { Weight } \\
\text { of } \\
\text { individu } \\
\text { al plant } \\
\text { (g) }\end{array}$ & $\begin{array}{c}\text { Green } \\
\text { fodder } \\
\text { yield (t ha- } \\
\text { 1) }\end{array}$ & $\begin{array}{l}\text { Dry } \\
\text { fodder } \\
\text { yield } \\
\left(\mathrm{t} \mathrm{ha}^{-1}\right)\end{array}$ \\
\hline $\begin{array}{l}\text { Black gram } 50 \mathrm{~kg} \\
\text { seed ha-1 (sole) }\left(\mathrm{T}_{2}\right)\end{array}$ & $48.59 \mathrm{a}$ & $3.47 \mathrm{a}$ & $10.40 \mathrm{a}$ & $\begin{array}{c}38.33 \\
\mathrm{jk}\end{array}$ & $47.87 \mathrm{a}$ & $12.49 \mathrm{kl}$ & $1.92 \mathrm{hi}$ \\
\hline $\begin{array}{l}\text { Aus rice + Black } \\
\text { gram } 50 \mathrm{~kg} \text { seed ha } \\
\left.\text { ( } \mathrm{T}_{3}\right)\end{array}$ & $\begin{array}{l}48.05 \\
\mathrm{ab}\end{array}$ & $3.33 \mathrm{ab}$ & $\begin{array}{c}10.33 \\
\mathrm{ab}\end{array}$ & $37.33 \mathrm{k}$ & $47.17 \mathrm{a}$ & 11.981 & $1.79 \mathrm{i}$ \\
\hline $\begin{array}{l}\text { Black gram } 55 \mathrm{~kg} \\
\text { seed ha }{ }^{-1}(\text { sole })\left(\mathrm{T}_{4}\right)\end{array}$ & $\begin{array}{c}47.52 \\
\text { bc }\end{array}$ & $3.27 \mathrm{a}-\mathrm{c}$ & $\begin{array}{c}10.13 \\
a b\end{array}$ & $\begin{array}{l}40.33 \\
\mathrm{~h}-\mathrm{k}\end{array}$ & $46.20 \mathrm{ab}$ & $13.46 \mathrm{ij}$ & $2.16 \mathrm{fg}$ \\
\hline $\begin{array}{l}\text { Aus rice + Black } \\
\text { gram } 55 \mathrm{~kg} \text { seed ha } \\
\mathrm{T}_{\left(\mathrm{T}_{5}\right)}\end{array}$ & $\begin{array}{l}47.13 \\
\mathrm{~cd}\end{array}$ & $3.20 \mathrm{bc}$ & $\begin{array}{c}10.00 \\
\mathrm{ab}\end{array}$ & $\begin{array}{c}39.33 \mathrm{i}- \\
\mathrm{k}\end{array}$ & $45.90 \mathrm{ab}$ & $13.04 \mathrm{jk}$ & $2.06 \mathrm{gh}$ \\
\hline $\begin{array}{l}\text { Black gram } 60 \mathrm{~kg} \\
\text { seed ha }{ }^{-1}(\text { sole })\left(\mathrm{T}_{6}\right)\end{array}$ & $\begin{array}{c}46.51 \\
\mathrm{de}\end{array}$ & $\begin{array}{c}3.13 \mathrm{~b}- \\
\mathrm{d}\end{array}$ & $9.73 \mathrm{a}-\mathrm{c}$ & $\begin{array}{c}42.33 \mathrm{f}- \\
\mathrm{i}\end{array}$ & $\begin{array}{l}44.93 \mathrm{a}- \\
\mathrm{c}\end{array}$ & $14.44 \mathrm{gh}$ & $2.38 \mathrm{~d}-\mathrm{f}$ \\
\hline $\begin{array}{l}\text { Aus rice + Black } \\
\text { gram } 60 \mathrm{~kg} \text { seed ha } \\
\left.\mathrm{T}_{7}\right)\end{array}$ & $46.17 \mathrm{e}$ & $3.07 \mathrm{c}-\mathrm{e}$ & $9.67 \mathrm{a}-\mathrm{c}$ & $\begin{array}{c}41.33 \\
g-j\end{array}$ & $\begin{array}{l}43.40 \mathrm{~b}- \\
\quad \mathrm{d}\end{array}$ & $14.08 \mathrm{hi}$ & 2.31 ef \\
\hline
\end{tabular}




\begin{tabular}{|c|c|c|c|c|c|c|c|}
\hline $\begin{array}{l}\text { Black gram } 65 \mathrm{~kg} \\
\text { seed ha }{ }^{-1}(\mathrm{sole})\left(\mathrm{T}_{8}\right)\end{array}$ & $45.49 \mathrm{f}$ & $2.93 \mathrm{~d}-\mathrm{f}$ & $\begin{array}{l}9.53 \mathrm{a}- \\
\mathrm{d}\end{array}$ & $\begin{array}{c}44.33 \\
\mathrm{~d}-\mathrm{g}\end{array}$ & $\begin{array}{c}42.14 \mathrm{c}- \\
\mathrm{e}\end{array}$ & 15.52 ef & $2.70 \mathrm{a}-\mathrm{c}$ \\
\hline $\begin{array}{l}\text { Aus rice + Black } \\
\text { gram } 65 \mathrm{~kg} \text { seed ha } \\
{ }_{\left(\mathrm{T}_{9}\right)}\end{array}$ & $45.15 \mathrm{f}$ & $\begin{array}{l}2.87 \mathrm{e}- \\
\mathrm{g}\end{array}$ & $\begin{array}{l}9.40 \mathrm{~b}- \\
\mathrm{e}\end{array}$ & $\begin{array}{l}43.33 \\
\text { e-h }\end{array}$ & $42.03 \mathrm{de}$ & $15.04 \mathrm{fg}$ & $2.45 \mathrm{c}-\mathrm{e}$ \\
\hline $\begin{array}{l}\text { Black gram } 70 \mathrm{~kg} \\
\text { seed ha-1 (sole) } \\
\left(T_{10}\right)\end{array}$ & $44.51 \mathrm{~g}$ & $2.80 \mathrm{f}-\mathrm{h}$ & $8.93 \mathrm{c}-\mathrm{f}$ & $\begin{array}{c}46.33 \\
b-e\end{array}$ & $\begin{array}{l}40.73 \mathrm{~d}- \\
\mathrm{f}\end{array}$ & $16.47 \mathrm{~cd}$ & $2.85 \mathrm{a}$ \\
\hline $\begin{array}{l}\text { Aus rice + Black } \\
\text { gram } 70 \mathrm{~kg} \text { seed ha } \\
\left(\mathrm{T}_{11}\right)\end{array}$ & $44.18 \mathrm{~g}$ & $2.73 \mathrm{f}-\mathrm{i}$ & $8.80 \mathrm{c}-\mathrm{f}$ & $\begin{array}{l}45.33 \\
\mathrm{c-f}\end{array}$ & $\begin{array}{c}39.54 \mathrm{e}- \\
\mathrm{g}\end{array}$ & $16.07 \mathrm{de}$ & $2.37 \mathrm{~d}-\mathrm{f}$ \\
\hline $\begin{array}{l}\text { Black gram } 75 \mathrm{~kg} \\
\text { seed ha }{ }^{-1}(\text { sole }) \\
\left(T_{12}\right)\end{array}$ & $43.51 \mathrm{~h}$ & $2.67 \mathrm{~g}-\mathrm{j}$ & $8.67 \mathrm{~d}-\mathrm{f}$ & $\begin{array}{l}48.33 \\
\text { a-c }\end{array}$ & $\begin{array}{c}38.61 \mathrm{f}- \\
\mathrm{h}\end{array}$ & $17.04 \mathrm{a}-\mathrm{c}$ & $2.75 \mathrm{ab}$ \\
\hline $\begin{array}{l}\text { Aus rice }+ \text { Black } \\
\text { gram } 75 \mathrm{~kg} \text { seed ha } \\
\mathrm{I}_{\left(\mathrm{T}_{13}\right)}\end{array}$ & $\begin{array}{c}43.06 \\
\mathrm{hi}\end{array}$ & $2.60 \mathrm{~h}-\mathrm{j}$ & $8.53 \mathrm{ef}$ & $\begin{array}{l}47.33 \\
\text { a-d }\end{array}$ & $\begin{array}{c}37.25 \mathrm{~g}- \\
\mathrm{i}\end{array}$ & $16.76 \mathrm{bc}$ & $\begin{array}{c}2.613 \mathrm{a}- \\
\mathrm{d}\end{array}$ \\
\hline $\begin{array}{l}\text { Black gram } 80 \mathrm{~kg} \\
\text { seed ha }{ }^{-1} \text { (sole) } \\
\left(\mathrm{T}_{14}\right)\end{array}$ & $42.54 \mathrm{ij}$ & $2.53 \mathrm{ij}$ & $8.33 \mathrm{f}$ & $50.33 \mathrm{a}$ & $36.31 \mathrm{hi}$ & $17.52 \mathrm{a}$ & $2.60 \mathrm{~b}-\mathrm{d}$ \\
\hline $\begin{array}{l}\text { Aus rice + Black } \\
\text { gram } 80 \mathrm{~kg} \text { seed ha } \\
\left(\mathrm{T}_{15}\right)\end{array}$ & $42.10 \mathrm{j}$ & $2.47 \mathrm{j}$ & $8.20 \mathrm{f}$ & $\begin{array}{l}49.33 \\
a b\end{array}$ & $35.35 \mathrm{i}$ & $17.27 \mathrm{ab}$ & $2.78 \mathrm{ab}$ \\
\hline CV (\%) & 0.83 & 4.38 & 5.54 & 4.60 & 3.79 & 2.53 & 5.50 \\
\hline
\end{tabular}

In a column, figures having similar letters or without letter do not differ significantly whereas figures having dissimilar letters differ significantly as per Duncan's Multiple Range Test (DMRT).

\section{Dry fodder yield}

Dry fodder yield of blackgram was significantly affected by seed rate of blackgram in Aus rice-blackgram intercropping system and sole cropping. Higher dry fodder yield $\left(2.85 \mathrm{tha}^{-1}\right)$ was observed in blackgram fodder sole cropping at $70 \mathrm{~kg}$ seed $\mathrm{ha}^{-1}$, which was followed by blackgram sole cropping at 65 and $75 \mathrm{~kg}$ seed ha ${ }^{-1}$ and $A u$ s rice in row + blackgram at 75 and $80 \mathrm{~kg}$ seed ha ${ }^{-1}$. The lowest dry fodder yield $\left(1.79 \mathrm{t} \mathrm{ha}^{-1}\right)$ was found in Aus rice in row + blackgram fodder at $50 \mathrm{~kg}$ seed ha ${ }^{-1}$, which was similar to blackgram fodder sole cropping at $50 \mathrm{~kg}$ seed ha ${ }^{-1}$. Among the intercropping systems, dry fodder yield of blackgram showed the best performance $\left(2.78 \mathrm{t} \mathrm{ha}^{-1}\right)$ in Aus rice in row + blackgram at $80 \mathrm{~kg} \mathrm{seed} \mathrm{ha}^{-1}$. Variation of dry fodder yield of blackgram might be due to increasing seed rate in blackgram.

\section{Economic analysis}

\section{Gross return}

Gross return was significantly affected by seed rate of blackgram in Aus rice-blackgram intercropping system and sole cropping (Table 3). Higher gross return (Tk.64030 ha ${ }^{-1}$ ) was observed in Aus rice in row + blackgram fodder at $50 \mathrm{~kg} \mathrm{seed} \mathrm{ha}^{-1}$ followed by Aus rice in row + blackgram fodder at $55 \mathrm{~kg}$ seed ha ${ }^{-1}$. Similar results were reported by Kader et al. (1999) that gross return of Aus rice-mungbean fodder intercropping system was superior to sole cropping. The lowest gross return (Tk.12490 ha ${ }^{-1}$ ) was found in blackgram fodder sole cropping at $50 \mathrm{~kg}$ seed $\mathrm{ha}^{-1}$. Variation of gross return might be due to increase in blackgram 
seed rate and intercropping with Aus rice, grain and straw yields of Aus rice, yield of fodder and market price of the products. All intercropping systems, showed superior performance in terms of gross return compared to sole cropping because of higher grain and straw yields.

\section{Net return}

Net return was significantly affected by seed rate of blackgram in Aus rice-blackgram intercropping system and sole cropping (Table 3). Higher net return (Tk.37180 ha $\mathrm{a}^{-1}$ ) was observed in Aus rice in row + blackgram fodder at $50 \mathrm{~kg}$ seed ha ${ }^{-1}$, which was similar to Aus rice in row + blackgram fodder at $55 \mathrm{~kg}$ seed ha ${ }^{-1}$ (Tk.35460 ha ${ }^{-1}$ ). The superiority of grain, straw and biological yields and harvest index of Aus rice in the intercropping systems showed the highest in net return. Similar results were reported by Sarma and Shyam (1992). The lowest net return (Tk.5663 ha ${ }^{-1}$ ) was found in blackgram fodder sole cropping at $50 \mathrm{~kg}$ seed $\mathrm{ha}^{-1}$, which was similar to blackgram fodder sole cropping at $55,60,65,70,75$ and $80 \mathrm{~kg}$ seed $\mathrm{ha}^{-1}$. The fodder crop of sole cropping at various seed rates showed inferior performance with respect to net return. Variation of net return might be due to higher gross return.

Table 3. Gross return, net return and benefit cost ratio in Aus rice-black gram intercropping system

\begin{tabular}{|c|c|c|c|}
\hline Inter cropping treatment & $\begin{array}{c}\text { Gross return } \\
\left(\mathrm{Tk} \mathrm{ha}^{-1}\right)\end{array}$ & $\begin{array}{l}\text { Net return } \\
\left(\mathrm{Tk} \mathrm{ha}^{-1}\right)\end{array}$ & $\begin{array}{l}\text { Benefit cost } \\
\text { ratio (BCR) }\end{array}$ \\
\hline Aus rice sole sown in $25 \mathrm{~cm}$ apart $\left(\mathrm{T}_{1}\right)$ & $54410 \mathrm{~g}$ & $26590 \mathrm{~d}$ & $2.19 \mathrm{c}$ \\
\hline Black gram $50 \mathrm{~kg}$ seed ha ${ }^{-1}$ sole $\left(\mathrm{T}_{2}\right)$ & $12490 \mathrm{~m}$ & $5663 \mathrm{e}$ & $1.83 \mathrm{gh}$ \\
\hline Aus rice + Black gram $50 \mathrm{~kg}$ seed $\mathrm{ha}^{-1}\left(\mathrm{~T}_{3}\right)$ & $64030 \mathrm{a}$ & $37180 \mathrm{a}$ & $2.38 \mathrm{a}$ \\
\hline Black gram $55 \mathrm{~kg}$ seed ha- ${ }^{-1}$ sole $\left(\mathrm{T}_{4}\right)$ & 134601 & $6235 \mathrm{e}$ & $1.86 \mathrm{fg}$ \\
\hline Aus rice + Black gram $55 \mathrm{~kg}$ seed ha ${ }^{-1}\left(\mathrm{~T}_{5}\right)$ & $62640 \mathrm{~b}$ & $35460 \mathrm{a}$ & $2.30 \mathrm{~b}$ \\
\hline Black gram $60 \mathrm{~kg}$ seed ha $\mathrm{h}^{-1}$ sole $\left(\mathrm{T}_{6}\right)$ & $14480 \mathrm{k}$ & $6507 \mathrm{e}$ & $1.82 \mathrm{gh}$ \\
\hline Aus rice + Black gram $60 \mathrm{~kg}$ seed ha ${ }^{-1}\left(\mathrm{~T}_{7}\right)$ & $60210 \mathrm{c}$ & $32590 \mathrm{~b}$ & $2.18 \mathrm{c}$ \\
\hline Black gram $65 \mathrm{~kg}$ seed ha ${ }^{-1}$ sole $\left(T_{8}\right)$ & $15520 \mathrm{j}$ & $6930 \mathrm{e}$ & $1.81 \mathrm{gh}$ \\
\hline Aus rice + Black gram $65 \mathrm{~kg} \mathrm{seed} \mathrm{ha}^{-1}\left(\mathrm{~T}_{9}\right)$ & $58830 \mathrm{~d}$ & $30860 \mathrm{bc}$ & $2.11 \mathrm{~d}$ \\
\hline Black gram $70 \mathrm{~kg}$ seed ha ${ }^{-1}$ sole $\left(T_{10}\right)$ & $16470 \mathrm{i}$ & $7307 \mathrm{e}$ & $1.80 \mathrm{~h}$ \\
\hline Aus rice + Black gram $70 \mathrm{~kg} \mathrm{seed} \mathrm{ha}^{-1}\left(\mathrm{~T}_{11}\right)$ & $57450 \mathrm{e}$ & $28760 \mathrm{~cd}$ & $2.00 \mathrm{e}$ \\
\hline Black gram $75 \mathrm{~kg}$ seed ha ${ }^{-1}$ sole $\left(T_{12}\right)$ & $17040 \mathrm{hi}$ & $7557 \mathrm{e}$ & $1.80 \mathrm{~h}$ \\
\hline Aus rice + Black gram $75 \mathrm{~kg} \mathrm{seed} \mathrm{ha}^{-1}\left(\mathrm{~T}_{13}\right)$ & $56530 \mathrm{f}$ & $27620 \mathrm{~d}$ & $1.96 \mathrm{e}$ \\
\hline Black gram $80 \mathrm{~kg}$ seed ha ${ }^{-1}$ sole $\left(\mathrm{T}_{14}\right)$ & $17520 \mathrm{~h}$ & $7788 \mathrm{e}$ & $1.80 \mathrm{~h}$ \\
\hline Aus rice + Black gram $80 \mathrm{~kg}$ seed ha ${ }^{-1}\left(\mathrm{~T}_{15}\right)$ & $55990 \mathrm{f}$ & $26570 \mathrm{~d}$ & $1.90 \mathrm{f}$ \\
\hline CV (\%) & 1.07 & 7.07 & 1.61 \\
\hline
\end{tabular}

In a column, figures having similar letters do not differ significantly whereas figures having dissimilar letters differ significantly as per DMRT.

\section{Benefit cost ratio (BCR)}

Benefit cost ratio was significantly affected by seed rate of blackgram in $A$ As rice-blackgram intercropping treatment and sole cropping (Table 3). Higher benefit cost ratio (2.38) was observed in Aus rice in row + blackgram fodder at $50 \mathrm{~kg} \mathrm{seed} \mathrm{ha}^{-1}$ followed by Aus rice in row + blackgram fodder at $55 \mathrm{~kg}$ seed ha ${ }^{-1}(2.30)$. The lowest benefit cost ratio (1.80) was found in blackgram fodder as sole cropping at all seed rates. Among all the treatments, intercropping showed higher BCR compared to sole cropping of Aus rice and blackgram. Singh (2007) also reported similar observation that intercropping recorded significantly higher benefit cost ratio 
than their sole stand. The superiority of intercropping treatment with respect to gross and net returns showed the highest performance regarding benefit cost ratio.

\section{ONCLUSION}

From the results of Aus rice-blackgram intercropping treatment, it can be concluded that to minimize the deficit of fodder in the country with minimum rice grain yield loss and higher monetary benefit in Aus rice row sowing $25 \mathrm{~cm}$ apart, blackgram fodder sown at $50 \mathrm{~kg}$ seed $\mathrm{ha}^{-1}$ would be the promising fodder production technology.

\section{REFERENCES}

AIS. 2012. Krishi Diary (Agricultural Diary). Agril. Infor. Servi., Khamarbari, Farmgate, Dhaka-1215. pp.1-24. (In Bangla)

Awal, M. A., Koshi, H. and Ikeda, T. 2006. Radiation interception and use by maize/ peanut intercrop canopy. Agric. For. Meteorol. 139: 73-84

BARC (Bangladesh Agricultural Research Council). 1997. Fertilizer Recommendation Guide. Bangladesh Agril. Res. Coun. Farmgate, New Airport Road, Dhaka-1215. pp.13-21

Beets, W.C. 1982. Multiple Cropping and Tropical Farming Systems, Westview Press. Boulder, Colorado, USA. pp.125-127

Gomez, K. A, and Gomez, A, A, 1984. Statistical Procedures for Agricultural Research. Intl. Rice Res. Inst., Phillipines. pp.187-233

Hossain, M. A., Jahiruddin, M. and Khatun, F. 1995. Response of wheat and mustard to manganese, zinc and boron in calcareous soil. Bangladesh Journal of Crop Science, $6(1 \& 2): 51-56$

Jhansi, K. 2004. Management of shoot fly and stem borer incidence in fodder sorghum by intercropping with leguminous fodder crops. Indian Journal of Plant Protection, 32 (2): 139

Kabir, M. J., Hafeez, A. S. M. G., Haque, N., Kabir, M. A. and Rahaman, M. A. 2005. Comparative economic study of profitability among maize and its competitive crops. Bangladesh Journal of Agricultural Research, 30(1): 137-149

Kader, M. A., Sarkar, M. A. R., Saha, D. and Chanda, S.C. 1999. Intercropping of Aus ricemungbean fodder under different weeding regimes. Prog. Agric. 10 (1\&2): 145-149

Mandal, B. K., Dhara, M. C., Mandal, B. B. and Patra, B. C. 1989. Growth of rice, mungbean, soybean, peanut, ricebean and blackgram as sole and intercrops. Indian Joumal of Plant Physiology, 32 (4): 294-298

Midya, A., Bhattacharjee, K., Ghose, S. S. and Banik, P. 2005. Deferred seeding of blackgram (Phaseolus mungo) in rice (Oryza sativa) field on yield advantages and smothering of weeds. Journal of Agronomy and Crop Science, 191(3): 195-201

Pal, M., Path, B. P. and Singh, D. P. 1985. Effects of methods of sowing on wheat. Indian Journal of Agronomy, 30 (1): 110-111

Pramanik, M. Y. A. 2006. Effect of green manuring on transplant Aman rice and its residual effect on subsequent Boro rice. Ph. D. Dissert. Dept. Agron. Bangladesh Agril. Univ. Mymensingh-2202. p.24 
Sarma, D. and Shyam, N. N. 1992.Intercropping of summer pulses with direct seeded rice (Oryza sativa). Indian Journal of Agronomy, 37(4): 785-786

Sharma, K. C. 2008. Fodder production and economics of multi-cut pear millet (Pennisetum glaucum) intercropped with clusterbean (Cyamopsis tetragonoloba). Indian Journal of Agronomy, 53(1): $51-56$

Singh, C. V., Singh, R. K., Variar, M. and Chauhan, V. S.1992. Intercropping blackgram (Phaseolus mungo) and finger millet (Eleusine coracana) with upland rice (Oryza sativa). Indian Journal of Agronomy, 37(3): 553-554

Singh, J. K. 2007. Response of sunflower (Helianthus annuus) and french bean (Phaseolus vulgaris) intercropping of forage legumes and nitrogen nutrition. Indian Journal of Agronomy, 52(3): 208-211

Uddin, M. S., Satkar, M.A.R. and Haider, M. L.2012. Growing maize as fodder in Transplant Aman rice-Grasspea + Maize relay cropping system. Eco-friendly Agricultural Journal, 5(10):232-241

UNDP (United Nations Development Programme) and FAO (Food and Agriculture Organization). 1988. Land Resources Appraisal of Bangladesh for Agriculture Development. Rep.2. Agro-ecological Regions of Bangladesh. Bangladesh Agricultural Research Council, Dhaka. pp. 116-221 